\title{
PENDIDIKAN ISLAM PADA MASA ANDALUSIA DAN SISILIA
}

\author{
Sri wahyuni ${ }^{1}$ kartini $^{2}$ Yusuf burhan ${ }^{3}$ \\ ${ }^{1}$ Sekolah Tinggi Agama Islam(STAI) Darul Dakwah Wal-Irsyad(DDI) Kota Makassar,Indonesia. \\ Email: sriwahyuni8401burhan@gmail.com \\ ${ }^{2}$ Sekolah Tinggi Agama Islam(STAI) Darul Dakwah Wal-Irsyad (DDI) Kota Makassar,Indonesia. \\ Email: kartininini76@gmail.com \\ ${ }^{3}$ Sekolah Tinggi Agama Islam (STAI) Darul Dakwah Wal-Irsyad(DDI) Kota Makassar,Indonesia. \\ Email: yusufburhan8588@gmail.com
}

\begin{abstract}
ABSTRAK
Pendidikan Islam di kenal dan di yakini oleh penganut agama islam sebagai suatu pendidikan yang berasal dari ajaran islam yang menggambarkan bahwa pendidikan islam memiliki perbedaan yang sangat esensial dan pokok dengan model pendidikan lain.Dalam sejarah peradaban islam Andalusia dan Sisilia merupakan dua Negara di taklukkan oleh pemerintahan islam di bawah kepemimpinan bani umayyah dengan melalui kekuatan perang. Spanyol lebih banyak di kenal dengan nama Andalusia yang di ambil dari sebutan tanah semenanjung Liberia, julukan Andalusia berasal dari kata vandalusia yang artinya negeri bangsa vandal, karena sebagiaan selatan semenanjung ini pernah di kuasai bangsa vandal sebelum mereka di kalahkan oleh bangsa gotia barat pada abad V. Daerah ini di kuasai oleh islam setelah penguasa bani umayyah merebut tanah semenanjung ini dari bangsa gothi barat.
\end{abstract}

Kata kunci : Pendidikan Islam,Andalusia,Sisilia 


\section{A. PENDAHULUAN}

Penyerbuan(Invasi) yang dilakukan bani abbasiyah terhadap pemerintahan bani umayyah yang berpusat di damaskus menjadikan kekhalifahan berpindah ke tangan bani abbasiyah. Sebagai mana di ketahui setelah merebut kekuasaan tidak berhenti sampai di situ melainkan pengikut pengikut bani abbasiyah membantai seluruh keluarga bani umayyah dengan semena mena, walaupun demikian salah seorang anggota keluarga bani umayyah , Abdur Rahman I berhasil lolos dari ancaman maut tersebut.

Nama lengkap beliau adalah Abdur Rahman Bin Muawiyah bin Hisyam Bin Abdul Malik ia cucu hasyim abdul malik , khalifah ke 10 dinasti umayyah di damaskus abdur Rahman I di gelar Ad Dakhil (Penakluk yang masuk), gelar ini terkait keberhasilan menaklukkan dan memasuki spanyol setelah melalui perjuangan berat . beliau melakukan perjalanan menuju palestina,mesir,afrika utara, dan akhir nya masuk ke Andalusia.(Spanyol) yang kemudiaan tahun $138 \mathrm{H} / 755 \mathrm{M}$ didirikan kerajaan baru di negeri itu.

Sejak Amir Abdur Rahman I berkuasa berhasil membawa rakyat spanyol hidup tenteram demikian pula pada Abdur Rahman II sampai kepada pemerintahan khalifah Abdur Rahman III bahkan umat islam spanyol pada masa ini mencapai puncak kemajuan dan kejayaan menyaingi kejayaan daulat abbasiyah di Bagdad.

Abdur Rahman III memerintah sejak 300-350-H/912-961 M dan merupakan penguasa umayyah terbesar di spanyol,seluruh gerakan pengacau dan komplik politik dapat di atasi nya sehingga Negara dapat di amankan nya. Keberhasilan tersebut dapat di taklukkan di kota Elvira,jain,siville fatimiyyah untuk memperluas kekuasaan di spanyol.

Dan sesudah itu beliau berhasil menciptakan kemakmuran dan kemajuaan spanyol, ini dapat di lihat jalan raya sarana pengadaan air minum , pertaniaan , industri, perdagangan dan pendidikan mengalami kemajuaan yang pesat pada masa itu.

Setelah pemerintahan Abdur Rahman III wafat perubahan struktur kekuasaan yang mengakibatkan awal dari kehancuran khalifah bani umayyah di spanyol ketika Hasyim II naik tahta dalam usia baru sepuluh tahu. Karena usia nya yang masih muda sehingga yang menjalankan seluruh roda pemerintahan sepenuh nya di lakukan oleh Muhammad ibn Abi Amir.

Sejak periode ini para penguasa sudah tidak mampu mempertahan kan kejayaan spanyol sebagai pusat peradaban dunia bagian barat, dan bahkan kemajuaan peradaban islam hancur dan berakhir dengan pengusiran secara paksa seluruh umat islam di spanyol. 


\section{B. PEMBAHASAN}

A. Mundur nya Islam di spanyol.

Kemunduran islam yang berakibat fatal terhadap seluru sendi sendi islam di spanyol, maka terdapat dua factor penyebab Yaitu :

a.Penyebab dari dalam(internal)

1. Sistem pengangkatan kekhalifahan kurang jelas.

Karena system pengangkatan kekhalifahan kurang jelas, maka di antara keluarga

bani

Umayyah saling memperebutkan kekuasaan, mereka saling mengklaim diri nya bahwa ia merasa lebih berhak untuk menjadi khalifah, di samping itu pula boleh jadi kalangan pembesar pembesar kerajaan yang bukan dari kalangan mereka juga berambisi menduduki kekhalifahan.

Ketika kekhalifahan Hakam II pada tahun $350 \mathrm{H} / 961 \mathrm{M}$ dalam usia 45 tahun naik menjadi khalifah mengantikan bapak nya abdur rahman III ( 921/961) M, Beliau merupakan khalifah ke dua dalam sejarah daulat bani umayyah di Andalusia.

Beliau wafat pada tahun $976 \mathrm{M}$ dalam usia 62 tahun dan masa pemerintahan nya 17 tahun lama nya kemudiaan di gantikan putra nya hisyam II ( 976-1009) M yang masih usia nya 10 tahun, oleh karena masih muda belia maka jabatan mursyih lil amri ( pemangku kuasa) bagi pelaksanaan pemerintahan umum di jabat oleh Mughairah ibn Abdur rahman III saudara bapak nya.

Amir Mughairah tidak lama berkuasa, karena mati dalam perebutan kekuasaan, tragedy tersebut buat pertama kali dalam sejarah daulat umayyah di spanyol, dan merupakan persekongkolan istana yang di kepalai oleh Al Hajib jafar ibn Utsman Al- shahfi yang semenjak khalifah Al Hakam II telah memangku jabatan Al hajib. Selanjut nya pelaksana kekuasaan berada pada wasir Muhammad ibn amir mendapat gelar mulk al- Mansur yang kemudian menjadi tokoh terkenal di kemudiaan hari, ia terjun ke medan perang membawa tentara nya dan berhasil memenangkan setiap peperangan yang di hadapi nya, sedangkan khalifah hanya tinggal terkurung di dalam pekarangan istana, hal ini pula awl melemah nya otoritas kekhalifahan.

Sepeningal Al Mulk Mansur yang berkuasa sejak 976-1003 M maka terjadi lah kemelut yang berkelanjutan di dalam perebutan kekuasaan sampai daulat spanyol umayyah di spanyol runtuh, peristiwa ini dalam tempo 29 tahun saja sepeninggal mulk al Mansur yaitu antara tahun 
Semua kejadiaan tersebut menandakan bahwa peralihan dari satu khalifah ke khalifah berikut nya tidak ada peraturan yang mengikat, akibat nya di antara keluarga istana merasa punya hak untuk menduduki jabatan khalifah, sehingga dengan mudah terjadi perebutan kekuasaan di antara keturunan keturunan bani umayyah, yang datang kemudian lebih lemah dari yang terdahulu, perang saudara tak terhindar kan padahal mereka sesame umat islam.

2. Muncul nya kerajaan kerajaan kecil.

Tidak berapa lama Hisyam II merebut khalifah untuk kedua kali nya, cordova sebagai pusat ke khalifahan di spanyol di landa kekacauan politik akhir nya pada tahun $1031 \mathrm{M}$ dewan menteri yang memerintah cordoba menghapuskan jabatan khalifah .

Permusuhan antara elit propensial elit pedagang perkotaan, antara warga kota dan tentara berber, antara non Arab yang baru masuk islam dengan bangsa Arab, menjadikan Negara muslim spanyol tidak mampu memperkokoh rezim . sebuah pemerintahan imperial di pusat di gantikan oleh sejumlah rezim propensial yang lebih kecil, kesatuaan pemerintahan kekhalifahan tewrhapus dan spanyol terbagi bagi menjadi kesultanan kecil, yang di sebut mulk thawaif, atau sejumlah kerajaan kecil (antara 1030-1090), tentara Arab, Slavia, dan tentara berber serta kalangan elit lokal masing-masing menjadi berkuasa.

Meskipun terjadi rezim propensial, tetapi ada suatu hal yang perlu di catat bahwa masyarakat spanyol tidak turut terpecah- pecah, hokum islam dan sebuah identitas muslim Arab tetap di terima secara universal, peradaban dan ilmu pengetahuan, keseniaan dan kebudayaan islam spanyol memuncak perkembangan nya , setiap dinasti(raja) di Malaga,Toledo,sevilla, Granada dan lain lain berusaha menyaingi cordova. Akan tetapi berapa tahun kemudiaan perpecahan politik yang sedemikian menghangat sangat mengancam keberadaan peradaban islam bangsa spanyol.

\section{Fanatisme Kesukuaan}

Semenjak kematiaan Abdur Rahman III pemeluk pemeluk islam yang baru tidak dapat menerima sistem aristokrasi kearaban, mereka ini merupakan pihak pertama yang menentang kekhalifahan umayyah, sehingga muncul dua kekuatan terbesar yaitu berber dan slavia.

Beberapa suku saling memperebutkan supremasi kesukuan nya dan bahkan berusaha mendirikan sebuah Negara yang merdeka.

Kalangan orang spanyol dan berber memandang bangsa arab sebagai orang asing atau kaum pendatang, maka keberadaan pemerintah Arab di spanyol tidak berhasil menegakkan ikatan kebangsaan di tengah-tengah keragaman ras dan suku, akibat nya imperium islam spanyol terpecah menjadi sejumlah kelompok yang saling bertentangan sehingga mempercepat kehancuran pemerintah muslim di spanyol. 


\section{Kesulitan ekonomi}

Pada paruh kedua para penguasa islam spanyol, membangun kota dan mengembangkan ilmu pengetahuan, dengan sangat serius ,sehingga lalai membina perkonomiaan , akibat nya timbul kesulitan ekonomi yang amat memberat kan dan mempengaruhi kondisi politik dan militer. Dengan muncul nya dinasti-dinasti kecil menyebabkan kondisi politikn tidak stabil dan menyebabkan perekonomiaan morat marik.

b. penyebab dari luar(Eksternal)

1. Karena wilayah spanyol terpencil.

Kondisi wilayah turut mempengaruhi kemunduran islam di spanyol, spanyol bagaikan daerah dari dunia islam yang lain, mereka selalu berjuang sendiri tanpa mendapat bantuan kecuali dari afrika utara.

Dengan demikian tidak ada kekuatan alternatif yang mampu membendung kebangkitan Kristen di spanyol.

2. Komplik antara islam dengan Kristen

Sejak islam masuk di spanyol, para penguasaha islam tidak melakukan islamisasi secara sempurna, kerajan-kerajaan Kristen yang di taklukkan di biarkan pada hokum dan adat mereka, asal mereka membayar upeti, di samping itu kehadiran orang arab memperkuat rasa kebangsaan (nasionalisme) orang Kristen spanyol, sehingga tidak pernah berhenti pertentangfan antara islam dengan Kristen dan setelah abad kemudian raja-raja Kristen mempersiapkan diri untuk merebut kembali spanyol.

Dengan muncul nya disintegrasi di Negara Negara muslim pada abad sebelas mengantarkan pada pesat nya ekspansi sejumlah kerajaan Kristen, guna mempersatu kerajaan castile, leon dan gacilia pada tahun 1085 Alfonso VI menaklukkan Toledo ini merupakan awal pecah nya perang antara pihak muslim dengan Kristen. Selanjut nya di menangkan oleh Kristen tidak lama kemudian secara berurutan kerajaan Aragon merebut huesca(1096),saragosa(1118), tortosa(1148) dan Lerida( 1149).

Kemajuaan pihak Kristen di imbangi oleh pihak muslim, pada tahun 1082 sebuah delegasi ulama mengundang pihak al-murabithun untuk terlibat demi membela umat muslim spanyol, sehingga pada tahun 1086 pasukan kerajaan dari maroko menyebrangi spanyol dan akhir nya mengalahkan alfonso VI dan tahun 1090 sampai 1145 pasukan afrika utara tersebut berhasil menundukkan kota-kota muslim spanyol. 
B. Hapus nya islam Spanyol

Kebesaran dan keagungan Granada pun tidak dapat bertahan karena pada tahun 1469 kerajaan Ferdinand dari argon dan kerajaan Isabella dan castilia bersatu menyerang kekuasaan islam di bawah kekuasaan ibn amr al Ahmar di Granada, dimana daerah itu di kenal dengan nama Alhambra pada tanggal 2 januari $1492 \mathrm{M}$ bertepatan 2 rabiul Awal $897 \mathrm{H}$ ibu kota di Granada di kepung dan ditaklukkan oleh penguasa Kristen . dengan jatuh nya Granada kepada pihak Kristen merupakan awal berakhir nya sejarah warga muslim spanyol . pada waktu itu . Abdillah Muhammad raja dari kerajaan bani Al hamrah yang terakhir.

Setelah orang Kristen menguasai Andalusia, gerakan kristenisasi dilaksanakan yaitu memaksa orang islam menganut kembali agama Kristen. Dalam tahun 1499 di bawah pimpinan bapak akudosa(confessor) yaitu kardinal ximenes de cisnores di menyingkirkan semua buku Arab yang menguraikan tentang agama islam dengan jalan membakar nya.

\section{KESIMPULAN}

Andalusia dibawah kekuasaan islam mengalami kemajuaan pesat dan menjadi pusat ilmu pengetahuaan, sehingga menjadi tujuan pencari ilmu di abad pertengahan kemajuaan tersebut berangsur angsur pudar dan akhir nya hilang.

Kemunduran bahkan sampai hapus nya islam di spanyol dinpengaruhi dua faktor penyebab

Yaitu faktor dari dalam yang inti nya bahwa antara umat islam itu sendiri saling memerangi anatra satu dengan yang lain dengan yang lain nya, sedangkan faktor yang berasal dari luar adalah muncul dari pihak Kristen yang memang sejak semula kedatangan islam di spanyol telah tertanam dendam kesumat, mereka terasa terhina dan terpinggirkan akibat kekuasaanya di rebut oleh pejuang islam, mereka lama nya menunggu momentum yang tepat untuk menyerang raja-raja islam guna menguasai kembali kekuasaan di spanyol dan akhir nya mengusir secara paksa seluruh islam yang ada pada zaman itu.

Kota Granada satu satu nya kerajaan kecil pada waktu itu yang masih berdiri dan 
merupakan benteng pertahanan terakhir umat islam di spanyol akhir nya pada tahun $1492 \mathrm{M}$ jatuh lah kota Granada di tangan umat Kristen.

Sesungguh nya orang orang spanyol mengakui asal usul mereka yaitu

Dari bangsa Arab sebagai contoh Alcala Zamora adalah presiden pertama dari republic spanyol, Asal kata nama beliau adalah AI Qalah( benteng) Zamurah. 


\section{DAFTAR PUSTAKA}

Aziizu, B. Y.A. (2015). Tujuan Besar pendidikan adalah tindakan. Prosiding dan penelitiaan dan pengabdiaan kepada masyarakat,2(2)

Usman, H. A. Arsyam, M., \& Yusuf M (2021) january 17) ETIKA PERDAGANGAN DALAM ISLAM. https://doi.org/10.31219/osf.io/q6rbz 